\title{
Experience in the Education of Engineers from Vietnam in the Faculty of Mining and Geoengineering AGH
}

\author{
Marek $\mathrm{Cała}^{1}$, and Marek Borowski ${ }^{1, *}$ \\ ${ }^{1}$ AGH University Science and Technology, Faculty of Mining and Geoengineering, \\ A. Mickiewicza Av. 30, 30-059 Krakow, Poland
}

\begin{abstract}
The AGH University of Science and Technology collaborates closely with other universities, economic units, governmental and local administrative bodies. International cooperation plays a very important role in the academic research. The AGH University of Science and Technology has signed many collaboration agreements. They aim at multidimensional cooperation in the fields of education and academic research. AGH UST has always focused on collaboration with business and industry. In recent years, the global economy is undergoing massive transformations, what creates new challenges to companies and educational institutions that cater to the needs of industry. The expansion of business enterprises is largely dependent on their employees' expertise, skills and levels of competence. Certified engineers are provided by universities. Therefore, the qualifications of the graduates are determined by the curriculum and teaching methods, as well as the available educational and research facilities. Of equal importance is the qualified academic staff. Human activities in the field of engineering require finding solutions to problems of various nature and magnitude. An engineer's work consists in the design, construction, modification and maintenance of useful devices, processes and systems, using scientific and technical knowledge. In order to design complex engineering solutions, an engineer uses his imagination, experience, analytical skills, logical reasoning and makes conscious use of his knowledge. At the Faculty of Mining and Geoengineering of the AGH University of Science and Technology in Cracow, 15 engineers from Vietnam are studying Mining and Geology at the second-cycle studies (specialization: mine ventilation). The solutions proposed in the field of the engineers' education guarantee that foreign students gain both engineering knowledge and problem-solving skills. Therefore, the study programme was complemented by a series of practical aspects. Key words - engineers' education, international cooperation.
\end{abstract}

\section{Introduction}

International cooperation is regarded as one of the key elements in the educational and scientific development of the AGH University of Science and Technology and a way to boost

\footnotetext{
Corresponding author: marek.borowski@agh.edu.pl
} 
its international prestige. As a university of applied knowledge, the AGH UST has always been open to cooperation with various industries.

The university concluded more than 400 agreements about close cooperation with foreign universities in Europe, the Americas and Asia. In those agreements, the parties promise to join their efforts in many fields to promote education and scientific research. In addition, the AGH UST participates in numerous educational initiatives, including the Erasmus LLP programme. As part of its cooperation with other educational units, the university undertakes various organizational challenges to establish research centres, technology development centres and intercollegiate laboratories, to name just a few. The AGH UST strives to develop intercollegiate courses, create new interdisciplinary faculties and move studying to an increasingly international level. These activities are consistent with the university's priorities, which include making university education international, a challenge faced by potential partners worldwide, especially in the developing countries.

In particular, the longest-standing partners of the AGH UST are Asian countries, including Vietnam, with which the university collaborates on educating geologists, mining engineers and specialists in other fields.

In 2012, Professor Tadeusz Słomka, the rector of the AGH UST, and Le Minh Chuan, the President of VINACOMIN, signed a general agreement. One of its objectives was to start masters courses for a group of Vietnamese students. It was not until September 2014, however, that a delegation of the VINACOMIN Group paid a working visit at the Faculty of Mining and Geoengineering. As a result, a detailed agreement was concluded, and 15 engineers from Vietnam started a second-cycle master's programme in 2015. The agreement specified details concerning the financing, accommodation and other issues related to the stay of Vietnamese students in Poland. Based on the agreement, a detailed syllabus of the specialization was elaborated and the relevant legal proceedings were initiated to register the new unit. It should be emphasised that a special curriculum was designed to meet the specific requirements of the VINACOMIN Group. In the curriculum, emphasis was placed on gaining relevant knowledge and practical skills in the fields of mine ventilation systems and preventing natural hazards, especially endogenous fire hazard.

\section{Aspects of educating engineers}

In recent years, the global economy is undergoing massive transformations, which creates new challenges to companies and educational institutions that cater to the needs of industry. The expansion of business enterprises is largely dependent on their employees' expertise, skills and levels of competence. Certified engineers are provided by universities. Therefore, the qualifications of the graduates are determined by the curriculum and teaching methods, as well as the available educational and research facilities. Of equal importance is the qualified academic staff. The paramount importance of those issues results from the challenges and transitions that are taking place worldwide. It is possible to identify the following key factors [2]:

- technological advances, meaning that without ongoing education of engineers the economy will lose its competitive edge. For this reason, it is vital to bear in mind that knowledge becomes outdated and new fields appear, which calls for an interdisciplinary approach. Consequently, engineers are expected to be proficient not only in their chosen specialization, but also in a range of other fields.

- globalization of markets, which removes limitations to communication and trade, allowing businesses to expand their activities. New markets and new ways to exchange information and acquire knowledge emerge. For this reason, it is necessary to have a knowledge of various cultures and to adjust the strategies of human resources management accordingly, as well as educational opportunities. 
- the dissemination and recording of information in today's world takes place electronically. As a result, a huge amount of information has become easily accessible. In the myriad of information, however, it is extremely difficult to identify the useful bits and to verify, select and integrate information.

- threats to the natural environment caused by the exploitation of limited natural resources, pollution and the resulting degradation of the ecosystem. Therefore, human activity should employ methods that protect the environment.

- increasing awareness and social responsibility means that apart from improving the standards of living, technology has a detrimental effect on human health because of pollution, its impact is revealed in environmental disasters, it causes the depletion of non-renewable resources, or facilitates the spreading of diseases and epidemics.

- the pace of changes caused by technological advances accelerates the evolution of tastes and consumer needs. In fact, the requirements of the industry are shaped by consumers.

In order to meet all these challenges, universities continuously adjust their curricula, in some cases designing new educational programmes, like in the case of the cooperation of the AGH UST with the VINACOMIN Group. At the same time, university students are made aware of the necessity to adapt to the changing reality and to continue education throughout their careers. Learning this skill is one of the objectives of university education. Moreover, any company - regardless of the technological solutions it employs - is only as efficient and effective as its employees. It is believed that the crucial asset of every organization, which determines its strategic potential, are intellectual resources, i.e. knowledge, skills, experience, culture, hierarchy of values, and a will to cooperate and share knowledge. At our university, we strive to foster the awareness of the above in our students. It can generally be stated that intellectual capital is a vital factor that affects the ability to stay competitive, win over new customers, or increase one's share of the market. The key element of the intellectual capital is knowledge, which becomes useless unless it is continuously updated. What follows is that effective management of an organization that is expected to develop provides opportunities to revise, update and expand knowledge. Adopting such a policy by the VINACOMIN Group should be appreciated. In addition, the choice of the AGH UST as a partner who will equip Vietnamese engineers with necessary qualifications was in all respects the right decision. The faculty set the following objectives of students' education:

- to gain knowledge (terminology, procedures),

- to learn about basic principles, theories and generalizations,

- to learn how to apply the acquired knowledge to problem-solving,

- to develop specialist skills, decision-making,

- to develop creativity, to provide opportunities for personal development, to learn how to be articulate in communication,

- to acquire analytical skills, to learn how to assess ideas and express opinions,

- to understand the necessity of updating one's knowledge and to learn how to do it.

\section{The competences of an engineer today}

Human activities in the field of engineering require finding solutions to problems of various nature and magnitude. An engineer's work consists in the design, construction, modification and maintenance of useful devices, processes and systems, using scientific and technical knowledge. In order to design complex engineering solutions, an engineer uses his imagination, experience, analytical skills, and logical reasoning, and makes conscious use of his or her knowledge. An engineer's knowledge comprises theory and relevant information, regarded as appropriate qualifications [1]:

- factual knowledge - "know-that", or facts, principles and rules, 
- procedural knowledge - "know-how", or algorithms and methods enabling us to apply theoretical knowledge,

- conceptual knowledge, gained through understanding, reflecting, and reflective learning

- metacognitive knowledge, i.e. knowledge about one's own cognitive processes and our ability to control them.

The key problem of knowledge transmission is to decide which type of knowledge should be emphasised for the education to be effective while maintaining a high quality of education.

The definitions of competence vary. The traditional notion of competence as a combination of knowledge, skills and capabilities seems to be outdated. Currently, a broader interpretation is preferred and the term is defined as 'all the qualities of an employee which are applied and developed during work, and are conducive to achieving results consistent with the strategic objectives of the organization' [4].

During the process of education, it is possible to develop: the competences of an employee or a group regarded as professional competences, or the competences of a team of employees, taking into account the needs of the company. As a rule, an engineer's curriculum focuses on professional competences, especially in the field of engineering. Nevertheless, the cooperation with the VINACOMIN Group made it necessary to modify the curriculum in such a way that the Vietnamese engineers were able to acquire the competences of a professional team.

Also, it should be observed that an engineer's professional profile is not limited to knowledge. Apart from providing would-be engineers with the necessary qualifications, the AGH UST makes efforts to teach its students to observe ethical standards and to develop a correct attitude towards their work, the community and the environment. These qualities are in a way hidden and are instilled from birth by educators and other people. It should be emphasised that engineers from Vietnam are characterized by high standards of behaviour in their approach to work, studying, collaborators and teachers. Figure 1 presents the qualities of a professional engineer, including knowledge and other aspects.

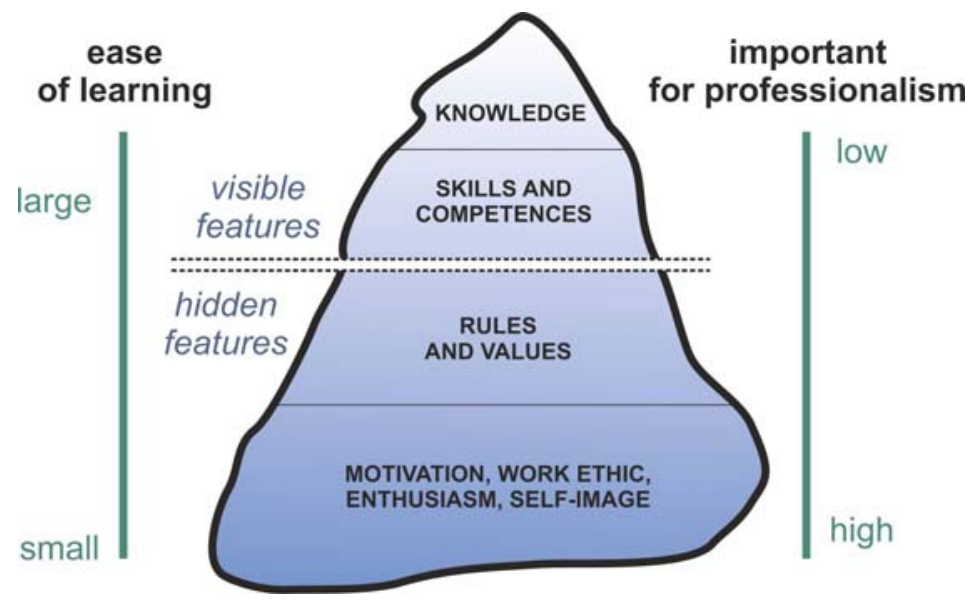

Fig. 1. The characteristics of a professional engineer [5]

Nevertheless, it is primarily the quality of education in the field of engineering that is decisive for an engineer's level of competence. Therefore, global organizations define educational standards for various fields, including of course engineering studies. The most widely known include ABET (Accreditation Board for Engineering and Technology), EURACE (EURopean ACcredited Engineer project), IEA (International Engineering Alliance), or JABEE (Japan Accreditation Board for Engineering Education) [3].

In Poland, there are standards for every field of study that are supposed to be met by the authors of curricula. Educational standards are based on the Bologna process, which in turn 
was largely based on the EUR-ACE system. The standards specify the minimum number of semesters, classes, core curriculum classes or majors, and the number of ECTS points. However, universities and faculties have sufficient autonomy to design unique curricula for their master's courses. Such unique curriculum was elaborated in the case under discussion to accommodate the requirements communicated by the VINACOMIN Group.

\section{The Vietnamese students' education}

In accordance with the agreement concluded between the AGH UST and the VINACOMIN Group, the engineers from Vietnam were to be educated in Polish. Therefore, in Vietnam the Group selected a group of 15 engineers who took a course in the Polish language in the VINACOMIN High School of Business Management in October 2014. From April 2015 onwards, the Vietnamese group started an intensive Polish language course at the Department of Foreign Languages at the AGH UST in Cracow. The classes lasted until the end of July, eight hours a day and five days a week. During this time, integration meetings with Polish students were organized for the participants. Also, the Vietnamese were taken on trips enabling them to acquire and practice elements of the Polish language.

In September 2015, the would-be students passed an exam in the Polish language at the B1 level. On 1 October 2015, during the matriculation ceremony held at the Faculty of Mining and Geoengineering, the Vietnamese engineers took a solemn oath and became fully-fledged students of the AGH UST.

From that moment on, the four-semester education process started. The curriculum comprised three core curriculum subjects, such as statistics, modern physics, and Polish, 25 vocational subjects and two non-vocational (humanistic) ones. The total number of hours was 1440, including 660 hours of lectures, 450 hours of tutorials, 135 hours of laboratory work and 195 hours of project work. In consideration of the educational standards, a student's workload was calculated at 30 ECTS points per semester. This number corresponds to 750 hours in a semester, half of which were classes and the other half was a student's own work. Also, four weeks of vocational training in a hard coal mine were included in the schedule.

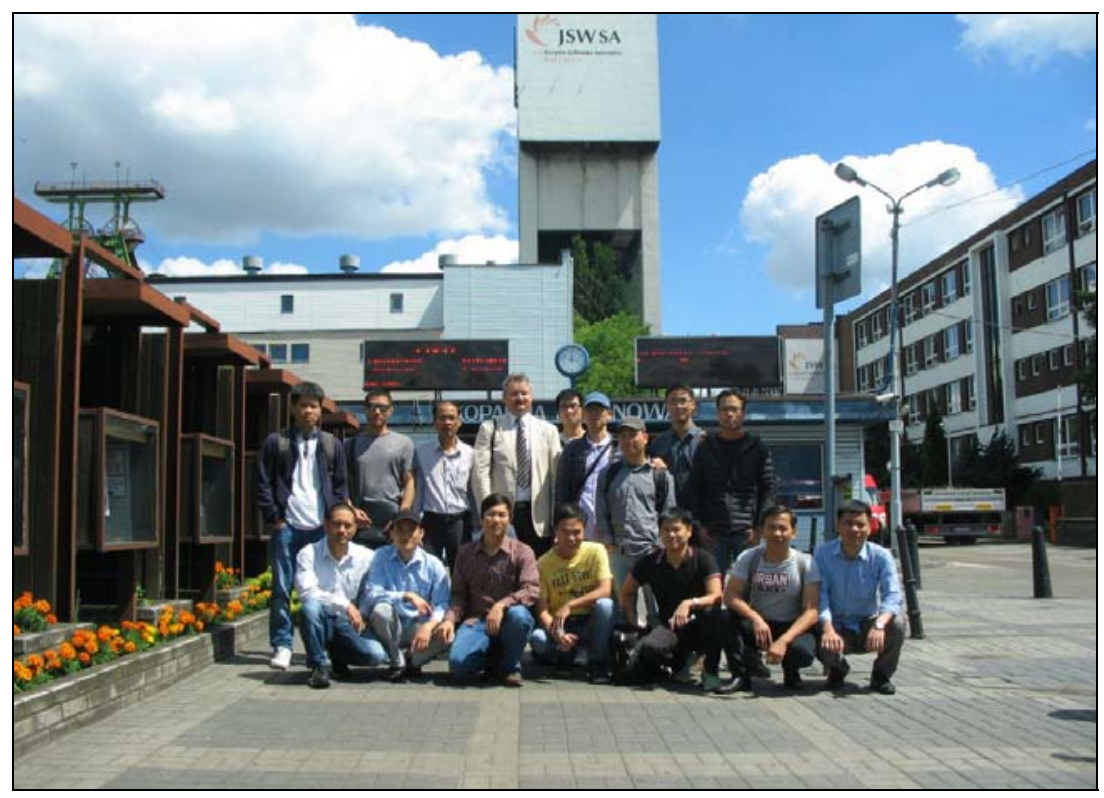

Fig. 2. Before entering the Borynia-Zofiówka - Jastrzębie, Part Borynia Coal Mine 
In order to provide the students with the competences required by the VINACOMIN Group, they have been taken on a number of technical excursions during the four semesters. As for the remaining four semesters, other technical excursions are planned as well; they are expected to supplement the students' knowledge about the most up-to-date technological solutions and the standards and procedures applied in hard coal mining.

In July 2016, a group of 15 mining engineers from Vietnamese mines, studying the specialization Mine Ventilation Systems at the Faculty of Mining and Geoengineering in Cracow, completed a training period in the Borynia-Zofiówka-Jastrzębie, Part Borynia Coal Mine (Fig. 2).

In July 2017, Vietnamese students defended a master's diploma dissertation. Figure 3 presents students just after their defence of master theses, taken in the traditional place - on the stairs of the building A-0.

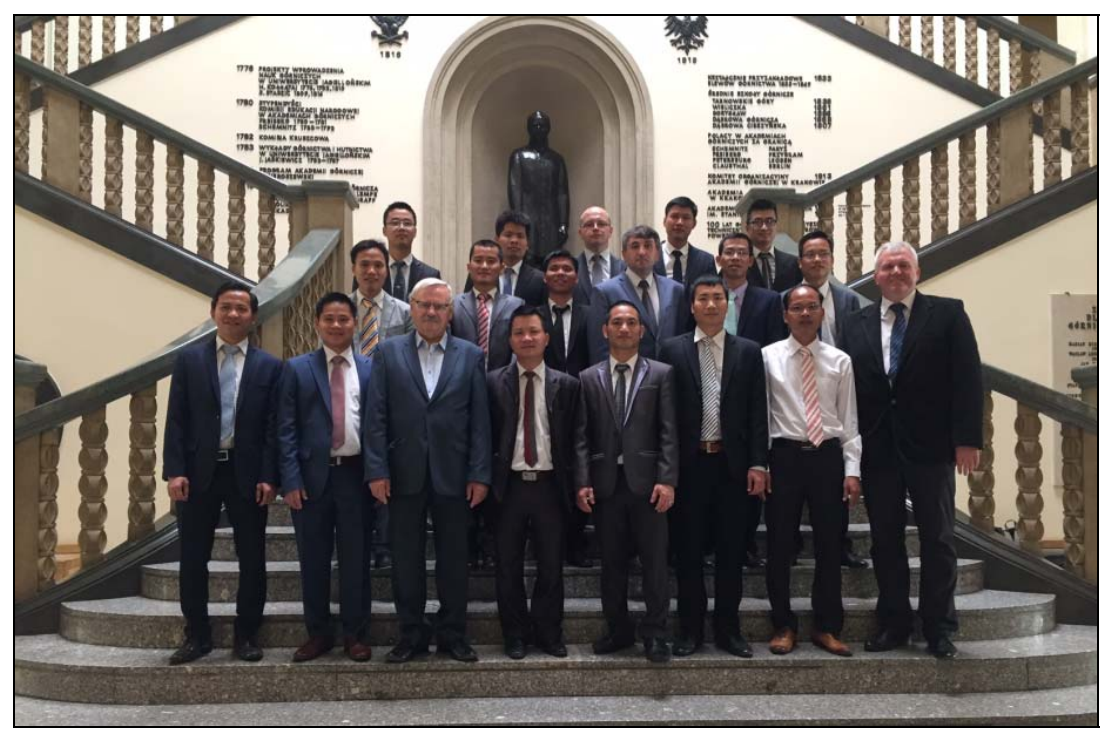

Fig. 3. Traditional picture taken after the master theses defence

\section{Conclusions}

In summary, it must be emphasised that the development of an organization depends to a great extent on the knowledge, skills and competences of the employees. Therefore, the AGH UST strives to design a curriculum that will equip the students with both general professional competence and specific competences needed by their company. In order to satisfy the requirements, a special curriculum was designed. Also, matching methods of teaching were selected and adequate educational facilities (specialist laboratories) were provided. Specially prepared academic staff employed at the faculty was appointed to the task. It must also be added that the Faculty of Mining and Geoengineering has the necessary organizational potential and can meet space requirements. Apart from mining, the faculty is also capable of educating Vietnamese students in the field of construction (with special emphasis on geomechanics) and environmental engineering.

The solutions implemented in order to rise to the challenge of educating Vietnamese students justify the conclusion that its objective has been attained. The students from Vietnam have completed the four semesters of a second-cycle master's programme with flying colours. The experience gathered so far raises hopes for the development of scientific and economic collaboration with Vietnamese companies that are interested in educating specialist staff. The 
activities pursued by the faculty are consistent with the priorities of the AGH UST, which include making university education international, a challenge faced by potential partners worldwide, especially in the developing countries.

\section{References}

1. L.W. Anderson, D.R. Krathwohl et al.: A Taxonomy for Learning, Teaching, and Assessing: A Revision of Bloom's Taxonomy of Educational Objectives, Longman, New York, (2000)

2. A. Kijewska, H. Przybyła: Społeczno-techniczne aspekty kształcenia inżynierskiego na potrzeby górnictwa, Wyd. Śląsk, Katowice. s. 139, (2013)

3. A. Kraśniewski: Ocena sytuacji w szkolnictwie wyższym w Polsce w zakresie opracowywania efektów kształcenia zwiąanych z wprowadzeniem Krajowej Struktury Kwalifikacji (Krajowych Ram Kwalifikacji). Dokument elektroniczny. http://www.nauka.gov.pl/g2/oryginal/2013_05/ffb483b704698fe6493477de4dfcd4a3.pdf

4. T. Oleksyn: Zarządzanie kompetencjami. Teoria i praktyka, Kraków, Oficyna Ekonomiczna, s. 260, (2010)

5. Słowiński B., Dobro $w$ działaniach inżynierskich - teoria i praktyka. Dokument elektroniczny. www.broneks.net/category/wyklady 